\title{
Fluoxetine-Induced Reversible Galactorrhea and Hyperprolactinemia: A Case Report
}

\author{
Fluoksetine Bağlı Geri Dönüşümlü Galaktore ve Hiperprolaktinemi: Bir Olgu Sunumu
}

\author{
Mehmet Hamdi Orum \\ Kahta State Hospital, Psychiatry Clinic, Adiyaman, Turkey.
}

\begin{abstract}
Selective serotonin reuptake inhibitors can lead to increased prolactin levels and galactorrhea. Herein, we reported a 40-year-old female patient who developed galactorrhea and hyperprolactinemia two weeks after initiation of fluoxetine 20 $\mathrm{mg} /$ day. Galactorrhea was discontinued after the fifth week of fluoxetine withdrawal and prolactin levels reached normal limits. The patient's depressive symptoms disappeared with citalopram $40 \mathrm{mg} /$ day and no similar side effects were observed during follow-up. Clinicians should be aware of the hyperprolactinemia and galactorrhea adverse effects of fluoxetine.
\end{abstract}

\section{$\ddot{O Z Z E T}$}

Seçici serotonin geri alım inhibitörleri prolactin düzeyi yükselmesine ve galaktoreye yol açabilir. Burada, 20 mg/gün fluoksetin tedavisine başlandıktan iki hafta sonra galaktore ve hiperprolaktinemi gelişen 40 yaşında bir kadın hastayı sunduk. Fluoksetin kesilmesinin beşinci haftasindan sonra galaktore kesildi ve prolaktin seviyeleri normal sinırlara ulaştt. Hastanin depresif semptomlart sitalopram $40 \mathrm{mg} / g u ̈ n$ ile ortadan kalktı ve takipte benzer yan etkilere rastlanmad. Klinisyenler, fluoksetinin hiperprolaktinemi ve galaktore yan etkilerine karşı uyanık olmalıdır.
Keywords:

Fluoxetine,

Galactorrhea,

Prolactin,

Hyperprolactinemia

\author{
Anahtar Kelimeler: \\ Fluoksetin, \\ Galaktore, \\ Prolaktin, \\ Hiperprolaktinemi
}

\section{INTRODUCTION}

Physiological conditions such as stress, sleep, physical exertion, coitus, pregnancy; pathologic conditions such as pituitary and hypothalamic disorders; primary hypothyroidism, seizures, chest wall trauma, herpes zoster infection, renal insufficiency, cirrhosis; pharmacologic agents such as antihypertensive, opiates, cocaine, metoclopramide, and psychotropic drugs can increase prolactin (PRL) levels and cause galactorrhea $(1,2)$. Antidepressants (ADs) such as selective serotonin reuptake inhibitors (SSRIs), tricyclic antidepressants, monoamine oxidase inhibitors can also cause hyperprolactinemia (3). Case reports on citalopram (4), paroxetine (5), sertraline (6), and fluoxetine-induced hyperprolactinemia (7) are available through the literature. However, the hyperprolactinemia and galactorrhea may develop with one of the aforementioned ADs, but not with another. Herein, we discussed a patient who developed galactorrhea and hyperprolactinemia due to fluoxetine and recovered with citalopram.

\section{CASE}

A 40-year-old married female patient was admitted to the psychiatric outpatient clinic with irritability, having no interest in things, lack of energy, and disturbed sleep. Physical examination was unremarkable. The patient was diagnosed with major depressive disorder (MDD) according to the fifth edition of diagnostic and statistical manual of mental disorders. Hamilton depression rating scale (HDRS) score was 41 (8). She was diagnosed with MDD five years ago and was managed with cognitive behavioral therapy. There was no history of using psychotropic drugs. The patient was managed by fluoxetine $20 \mathrm{mg} /$ day. Two weeks after starting fluoxetine, galactorrhea developed. Laboratory analysis revealed hyperprolactinemia (PRL level was $62 \mathrm{ng} / \mathrm{ml}$ [normal limits: 4.79-23.3 ng/ml]). The patient's thyroid, kidney and liver function tests were within normal limits. Magnetic resonance imaging of the brain was normal. The relatives of the patient stated that there was no change in dietary and fluid intake in recent days. The patient had no drug use other than fluoxetine. Systemic diseases and allergies were not reported. Hyperprolactinemia and galactorrhea were attributed to fluoxetine. Fluoxetine was stopped and citalopram $20 \mathrm{mg} /$ day was started. After 2 weeks, galactorrhea continued; the PRL level was found to be $45.3 \mathrm{ng} / \mathrm{ml}$; citalopram dose was increased to $40 \mathrm{mg} /$ day. In the fifth week after fluoxetine was discontinued, the PRL level was found to be $20.8 \mathrm{ng} / \mathrm{ml}$; galactorrhea did not continue. At the end of three months, the patient's MDD symptoms almost disappeared. HDRS score was 22. No similar side effects were reported during the follow-up of the patient. The patient and his relatives were warned about hyperprolactinemia and galac-torrhea due to fluoxetine use and written informed consent was received from the patient to publish her data. Naranjo Adverse Dug Reaction Probability Scale (NADRPS) score of the patient was 7 (9). 


\section{Orum}

\section{DISCUSSION}

This case report was evaluated as a case of hyperprolactinemia and galactorrhea due to fluoxetine; there was a temporal relationship between them. Other causes of hyperprolactinemia were excluded. The NADRPS score indicates a probable association between drug use and side effect (9). World Health Organization (WHO) defines 'probable' as an event or laboratory test abnormality, with reasonable time relationship to drug intake. WHO also says this relationship cannot be explained by disease or other drugs (10). Although the mechanism of hyperprolactinemia and galactorrhea by fluoxetine use has not yet been completely explained, several mechanisms are blamed. Fluoxetine blocks the serotonin reuptake transporter in the presynaptic terminal which results in sustained levels of 5-hydroxytryptamine (5-HT) in certain brain areas. Serotonergic activation via interneurons of prolactin-secreting factors is a possible mechanism. Serotonin may be mediated by serotonergic inhibition of prolactin inhibitory factors such as dopamine. Other mechanisms are the direct stimulation of the postsynaptic serotonergic receptors in the hypothalamus and the blockade of tuberoinfundibular dopaminergic neurons (7, 11). Mondal et al. (11), emphasized that fluoxetine induces an increase in prolactin via possible postsynaptic pathways. Chatterjee et al. (12), Papakostas et al. (13) reported an elevation in prolactin due to fluoxetine use. In our patient, citalopram was started after fluoxetine was stopped, and prolactin increase and galactorrhea were not observed during follow-up.

As a result, fluoxetine, a widely used SSRI, can cause hyperprolactinemia and galactorrhea. These side effects are reversible and can be switched to another SSRI. The physicians should be aware that patients taking fluoxetine could experience galactorrhea and prolactin elevation. Further studies are needed to explain the pathophysiological mechanisms by which fluoxetine affect prolactin.

Conflict of Interest: No conflict of interest was declared by the author.

\section{REFERENCES}

1. Majumdar A, Mangal NS. Hyperprolactinemia. J Hum Reprod Sci. 2013;6(3):168-175.

2. Malik AA, Aziz F, Beshyah SA, Aldahmani KM. Aetiologies of hyperprolactinaemia: A retrospective analysis from a tertiary healthcare centre. Sultan Qaboos Univ Med J. 2019 May;19(2):e129-e134.

3. Ajmal A, Joffe H, Nachtigall LB. Psychotropic-induced hyperprolactinemia: a clinical review. Psychosomatics. 2014;55(1):29-36.

4. Turkoglu S. Citalopram-induced galactorrhea in an adolescent. Clin Neuropharmacol. 2016;39(6):331.

5. Evrensel A, Önen Ünsalver B, Akyol A, Ceylan ME. A case of galactorrhea during paroxetine treatment. Int J Psychiatry Med. 2016;51(3):302-305.

6. Özten E, Hızl1-Sayar G, Göğcegöz-Gül I, Ceylan ME. Sertraline-induced galactorrhea. Arch Neuropsychiatr. 2015;52:202-203.

7. Peterson MC. Reversible galactorrhea and prolactin elevation related to fluoxetine use. Mayo Clin Proc. 2001;76:215-216.

8. Akdemir A, Örsel SD, Dağ İ, Türkçapar MH, İşcan N, Ozbay H. Hamilton depresyon derecelendirme ölçeği (HDDO)'nin geçerliliği-güvenilirliği ve klinikte kullanımı. Psikiyatri Psikoloji Psikofarmakoloji (3P) Dergisi. 1996;4(4):251-259.

9. Kose S, Akin E, Cetin M. Adverse drug reactions and causality: The Turkish version of naranjo adverse drug reactions probability scale. Psychiatr Clin Psychopharmacol. 2017;27(2):205-206.

10. Edwards IR, Biriell C. Harmonisation in pharmacovigilance. Drug Saf. 1994;10:93-102.

11. Mondal S, Saha I, Das S, Ganguly A, Das D, Tripathi SK. A new logical insight and putative mechanism behind fluoxetine-induced amenorrhea, hyperprolactinemia and galactorrhea in a case series. Ther Adv Psychopharmacol. 2013;3(6):322-334.

12. Chatterjee SS, Mitra S, Mallik N. Emerging hyperprolactinemic galactorrhea in obsessive compulsive disorder with a stable dose of fluoxetine. Clin Psychopharmacol Neurosci. 2015;13(3):316-318.

13. Papakostas GI, Miller KK, Petersen T, Sklarsky KG, Hilliker SE, Klibanski A, Fava M. Serum prolactin levels among outpatients with major depressive disorder during the acute phase of treatment with fluoxetine. J Clin Psychiatry. 2006;67(6):952-957. 